\title{
norden
}

Nordic Council of Ministers

Ved Stranden 18

DK-1061 Copenhagen K

www.norden.org

NORDISKE ARBEJDSPAPIRER

NORDIC WORKING PAPERS

\section{Exercise Autumn-2011}

Nordic-Baltic African Swine Fever Exercise

Nordic-Baltic Veterinary Contingency Group.

Editor Jørgen Westergaard

NA2013:907

http://dx.doi.org/10.6027/NA2013-907

This working paper has been published with financial support from the Nordic Council of Ministers. However, the contents of this working paper do not necessarily reflect the views, policies or recommendations of the Nordic Council of Ministers. 


\section{nordan}

Nordic Council of Ministers

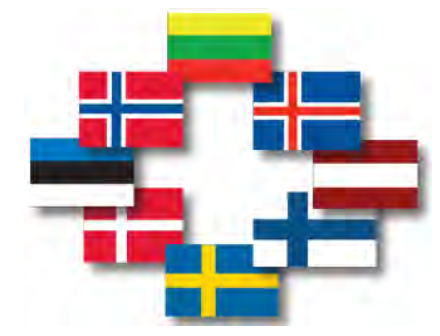

\section{Exercise AUTUMN-2011}

Nordic - Baltic African Swine Fever Exercise

October 2011

\section{PROCEEDINGS}

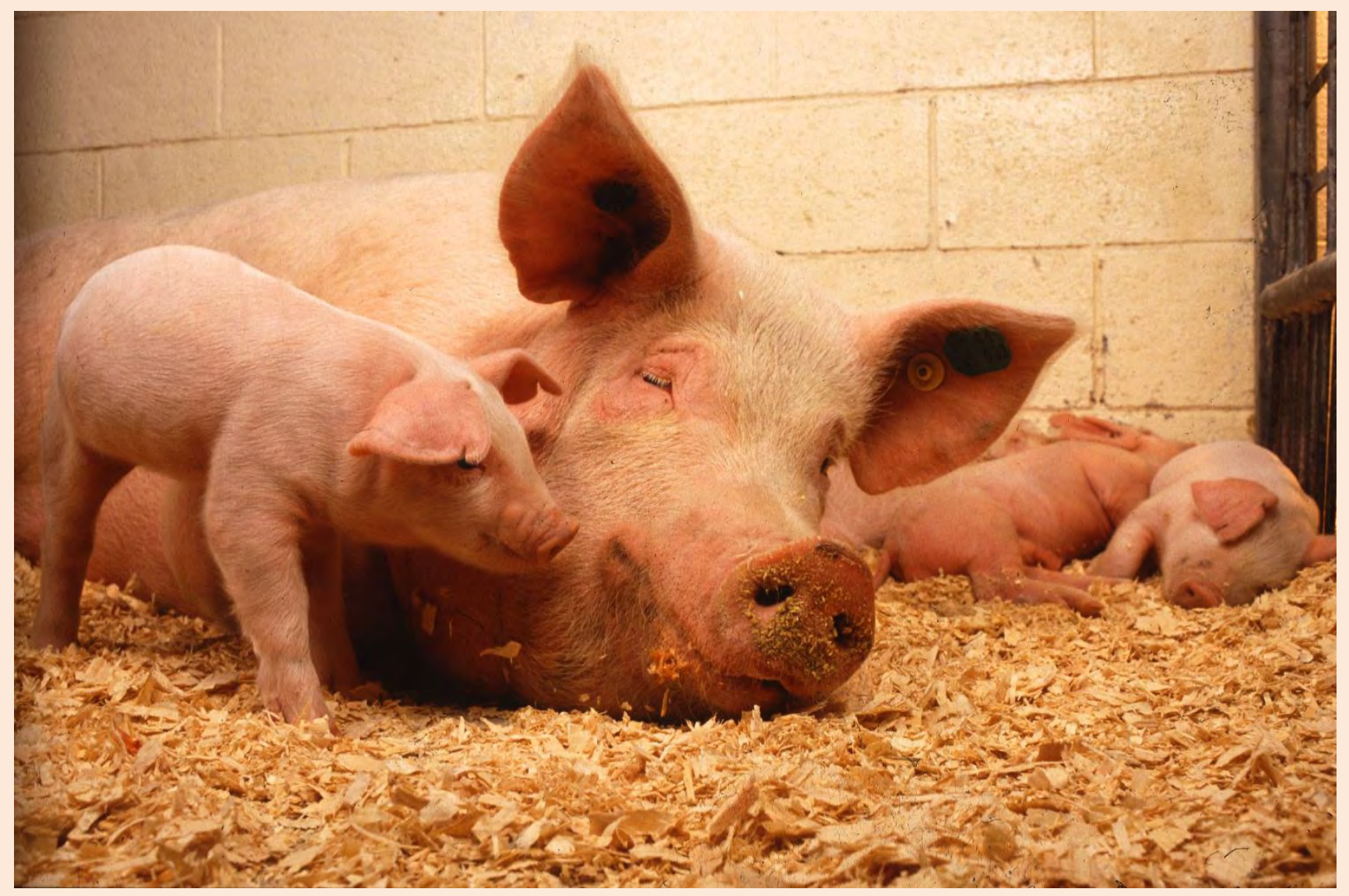




\section{Contents}

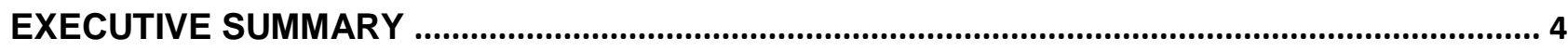

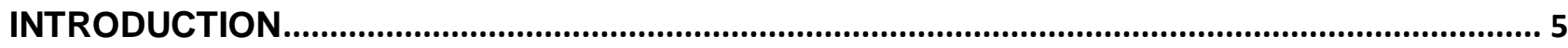

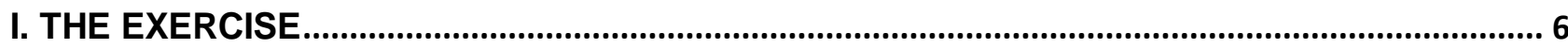

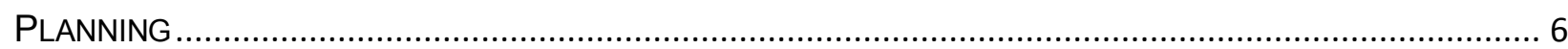

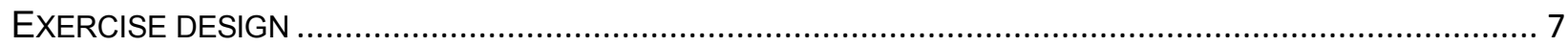

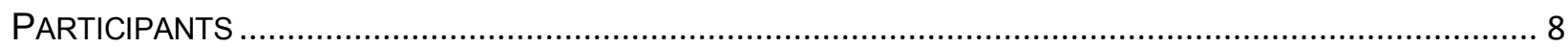

IMPLEMENTATION

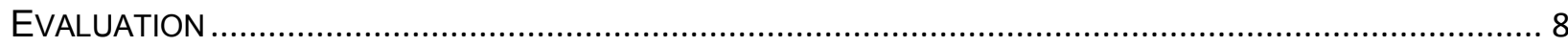

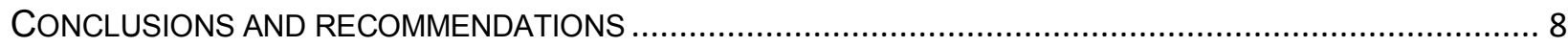

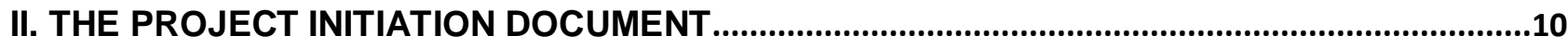

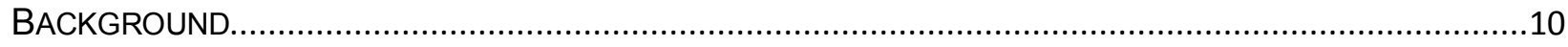

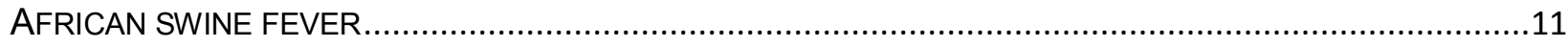

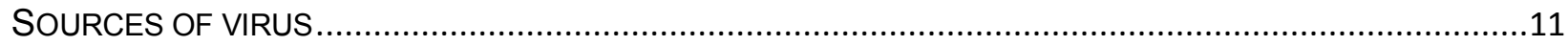

INCUBATION PERIOD

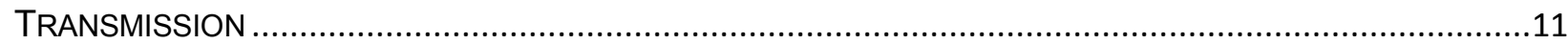

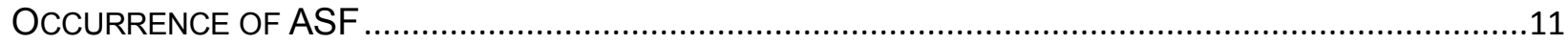

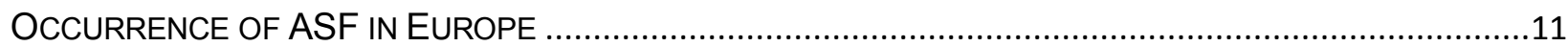

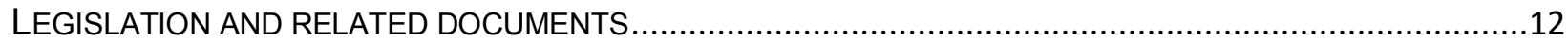

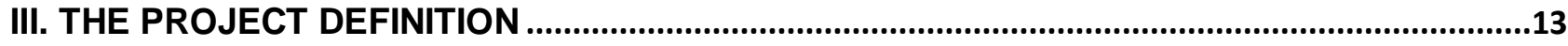

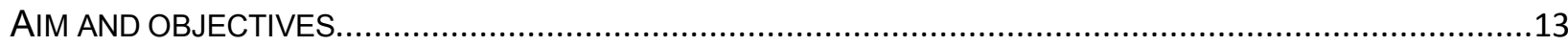

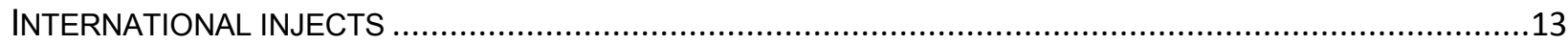

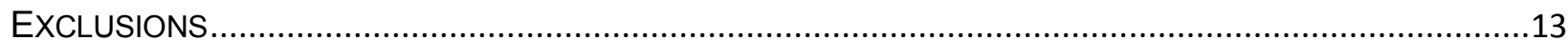

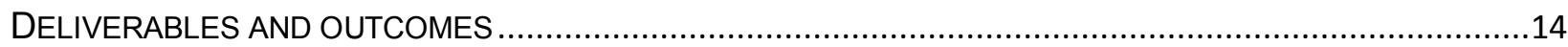

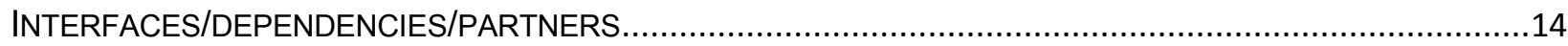

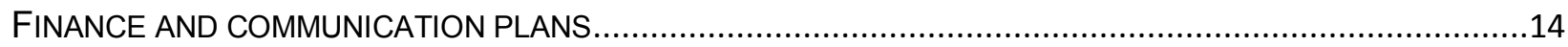

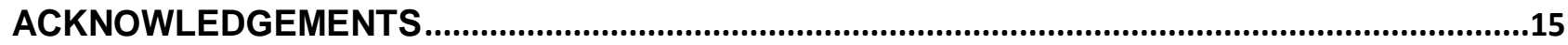

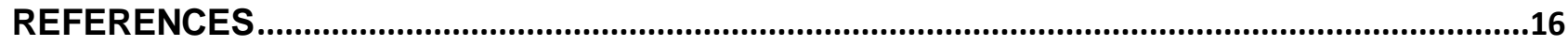

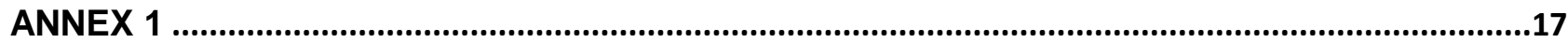

PROPOSED OBJECTIVES FOR A NATIONAL AFRICAN SWINE FEVER SIMULATION EXERCISE IN THE

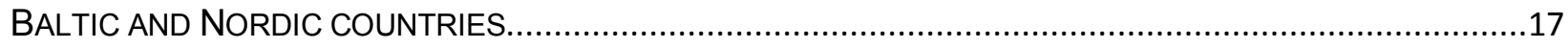

PROPOSED INTERNATIONAL INJECTS FOR AN AFRICAN SWINE FEVER SIMULATION EXERCISE TO BE CONDUCTED IN OCTOBER 2011 IN THE BALTIC AND NORDIC COUNTRIES .......................................18

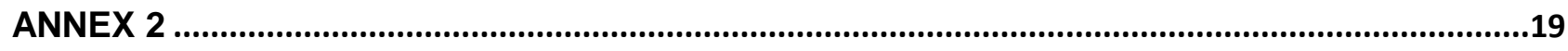

THE START OF "AUTUMN 2011” BY A SIMULATED ASF OUTBREAK IN DENMARK ..............................19

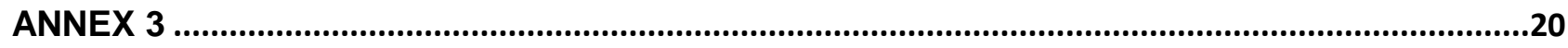

INFORMATION ON SCENARIOS PREPARED BY INDIVIDUAL IN THE NORDIC-BALTIC REGION ..................20

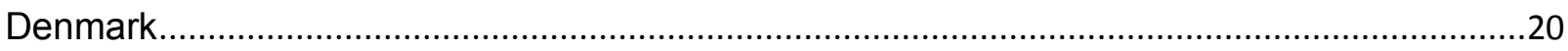

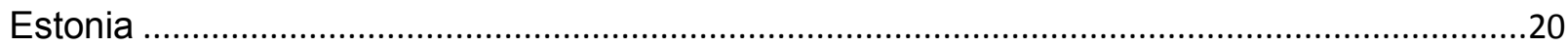

Finland

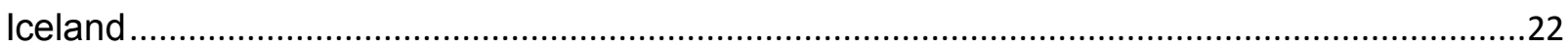




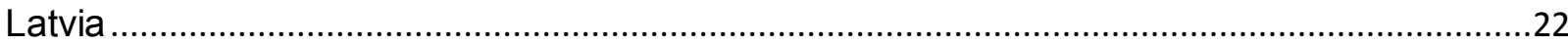

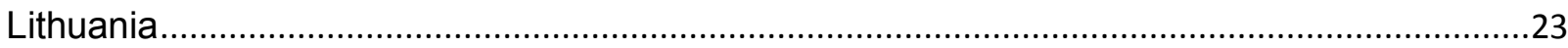

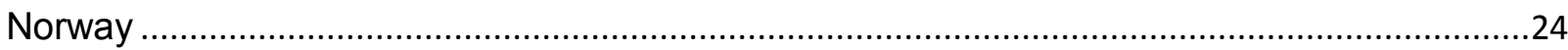

Sweden

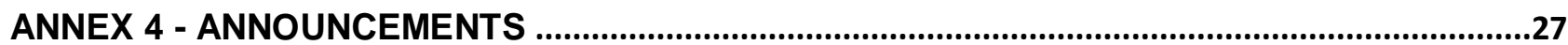

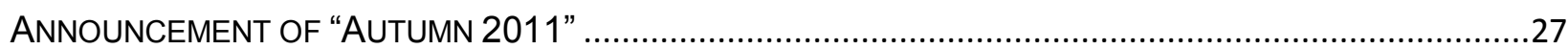

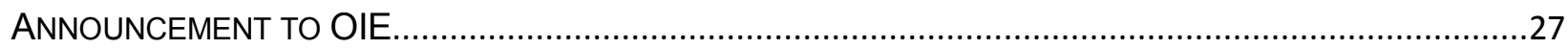

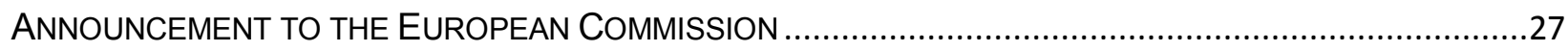

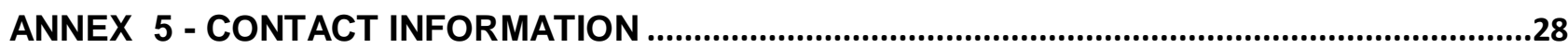

CONTACT INFORMATION TO THE CHIEF VETERINARY OFFICERS (CVO) IN THE BALTIC AND NORDIC

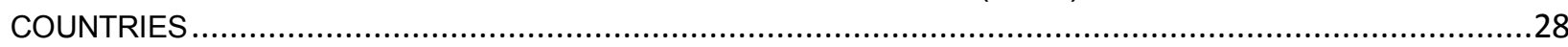

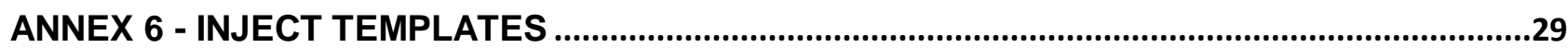

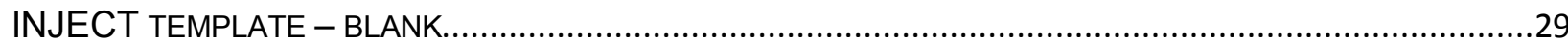

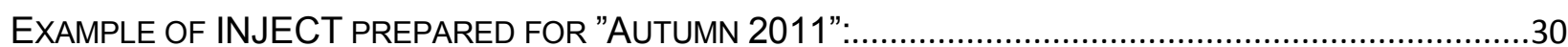

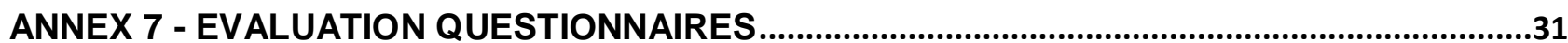




\section{Executive summary}

Simulation exercises are considered a very valuable tool for testing contingency plans established for the control and eradication of rapid spreading infectious animal diseases which may have devastating impact on livestock production and the society as a whole. A Nordic-Baltic simulation exercise was conducted in 2011 with the objectives included:

To test African swine fever contingency plans adopted respectively by Denmark, Estonia, Finland, Iceland, Latvia, Lithuania, Norway and Sweden

To enhance joint emergency preparedness among veterinary administrations in the Nordic and Baltic countries

To assist in the understanding of roles and responsibilities in the event of African swine fever outbreaks

To train the rapidly exchange of information between relevant persons in the Nordic and Baltic countries

African swine fever (ASF) was chosen for the simulation exercise as this disease since 2007 caused major problems in Georgia, Armenia, Azerbaijan and Russia and the presence of ASF in this geographical area has called for an up-scaling of disease preventive measures and increased disease preparedness throughout Europe. In this context it must be noted that the Membership of Russia in WTO may increase the trade in livestock and livestock products between Russia and countries in the Nordic Baltic region.

The simulation exercise was planned by the Nordic-Baltic Veterinary Contingency Group (N-B VCG) and conducted from 10 - 14 October 2011. It covered a number of activities related to:

- Inter-Nordic-Baltic issues

- National issues

The evaluation of the simulation exercise was based on a questionnaire developed as a tool to assist the countries in evaluating the parts of the exercise which primarily dealt with communication and training of personnel. Some countries conducted in addition evaluations related to certain national events.

All countries reported on a successful implementation of the ASF simulation exercise. The result from the evaluation showed that a better communication system should be established between the veterinary administrations of the Nordic Baltic region for use during extraordinary events. This applies for example to the use of telephone conferences, text messages and various means of modern electronic meeting facilities. The number of activities performed and number of veterinarians involved in the National part of the ASF simulation exercise varied from country to country. Certain weak points in the National Contingency Plans were elucidated by the exercise in some countries and steps to up-date and improve the national contingency plans have been discussed.

The over-riding conclusions that can be drawn from the exercise include that:

The inter-Nordic-Baltic African swine fever exercise has, during the different stages of preparation, implementation and evaluation, created an important and valuable network between the veterinary administrations of the Nordic and Baltic countries 
The issues highlighted by the "Autumn 2011" exercise contribute to the on-going process of testing the emergency preparedness for outbreaks of exotic animal diseases in the Nordic-Baltic region and ensuring the presence of robust and effective contingency plans.

\section{Introduction}

The Resolution on Nordic veterinary contingency planning adopted in 2005 by the Council of Ministers called for the urgent development of proposals in the Nordic countries for the establishment of various forms of close cooperation in veterinary contingency planning between the competent authorities, and that this should be followed up with appropriate initiatives in the relevant areas. It was envisioned that the cooperation could be established in a variety of areas, including the development of a strategic plan for the joint contingency co-operation and the holding of emergency exercises, training of emergency personnel, loan of experts and equipment, vaccination contingency and policy wording. Within the framework of the Resolution the Veterinary Administrations have established a Nordic - Baltic veterinary contingency group, which has focus on a common approach on disease prevention and disease preparedness at farm, regional, national and the Nordic-Baltic level. The activities carried out have included seminars and workshops on disease surveillance, risk assessments and disease outbreak management; simulation exercises concerning exotic animal diseases (foot and mouth disease, Bluetongue and West Nile Fever) and the preparation of a "Memorandum of Understanding on a Nordic Animal Health Emergency Reserve" which has been adopted by the Chief Veterinary Officer in all the Nordic and Baltic countries. The Memorandum provides the procedures for support and assistance to a country in the case of the occurrence of an outbreak of a serious animal disease. The importance of the Memorandum shall be seen in the light of outbreaks within the last $10-15$ years of livestock diseases in some highly industrialized countries. These outbreaks have shown how vulnerable agricultural systems can be when confronted with an outbreak of a highly infectious animal disease. Information of such situations is shown in Table I.

Table I. Costs and duration of outbreaks

\begin{tabular}{llllll}
\hline Country & Year & Disease & Costs & $\begin{array}{l}\text { Depopulation } \\
\text { of animals }\end{array}$ & $\begin{array}{l}\text { Duration } \\
\text { (days) }\end{array}$ \\
\hline The Netherlands* & 1997 & CSF & $€ 1.5$ billions & $€ 10,3$ millions & 459 \\
The UK** & 2001 & FMD & $£ 4.9$ billions & $£ 6.2$ millions & 223 \\
The Netherlands* & 2003 & Al & $€ 0.8$ billions & $€ 31,6$ millions & 175 \\
\hline *Ministy of Economic Affairs, Agriculture and Innovation, the Netherlands 2012. \\
**Department for Environment, Food and Rural Affairs (Defra), the United Kingdom, 2012. \\
Source: Westergaard, 2012. (2)
\end{tabular}

African swine fever (ASF), a viral disease of pigs characterized by fever, widespread haemorrhages and a high mortality rate, is endemic in sub-Saharan Africa and in a small location at Sardinia. The disease has since 2007 caused major problems in Georgia, Armenia, Azerbaijan and Russia and the presence of ASF in this new geographical area has called for an up-scaling of disease preventive measures and increased disease preparedness in the Nordic and Baltic countries.

With the aim to test ASF contingency plans prepared by the Nordic Baltic countries an ASF simulation exercise was carried out in 2011. This report describes the development, planning and execution of the exercise called "Autumn 2011". 


\section{The Exercise}

The preparation and implementation of a simulation exercise is a time consuming activity. Several types of exercises are described (1); with regard to "Autumn 2011" it was at an early time decided that the exercise should be an organized and controlled scenario-driven functional exercise. It should in general terms:

- Test the capability of an organization ( The Nordic Baltic Veterinary Administrations) to respond to an event

- Test multiple functions of the organization's operational plan ( African swine fever contingency plans)

- Focus on the coordination, integration of an organization's procedures (The veterinary administrations of the Nordic-Baltic countries)

\section{Planning}

Autumn 2011 was the product of inter-Nordic-Baltic cooperation spanning over a period of about 12 months. The initial meeting of the project team, The Nordic - Baltic Veterinary Contingency Group (N-B VCG), had focus on:

- Aim

- Objectives

- Time frame

Scenario and epidemiological links

The details of the exercise are given in chapter IV in the Project Initiation Document (PID).

The objectives of "Autumn 2011" were split into two major parts dealing with inter-Nordic - Baltic issues and national issues as shown below:

The objectives at inter-Nordic-Baltic level were:

- to train the rapid exchange of information between relevant persons in the Nordic and Baltic countries

- to make use of the Memorandum of Understanding on Nordic-Baltic Animal Health Emergency Reserve

- to explore the potential for exchange of resources of mobile equipment

Objectives at national level to include:

- To activate the National disease control centre

- To activate one or several Local Disease Control Centre(s)

- To carry out pig trace-back activities on national movements and on movements related to import and export of animals

- To test the capability of depopulating infected farms and in-contact farms

- To test procedures for disposal of carcasses from infected herds

The detailed specific objectives adopted by individual countries are shown in the PID, in chapter 3. 
The timeframe, 10 - 14 October 2011, was established at an early date during the preparatory work in an attempt to ensure that key persons such as Chief Veterinary Officers (CVO), Chairmen of farmers' organizations could reserve the dates for the simulation exercise. However, the content of the exercise was only known by the N-B VCG.

The scenario and epidemiological links during the simulated outbreaks were designed to be realistic and challenging. An outbreak of African swine fever (ASF) would initially occur in Denmark and the disease would rapidly be transmitted to other countries. The epidemiological links are illustrated in figure 1.

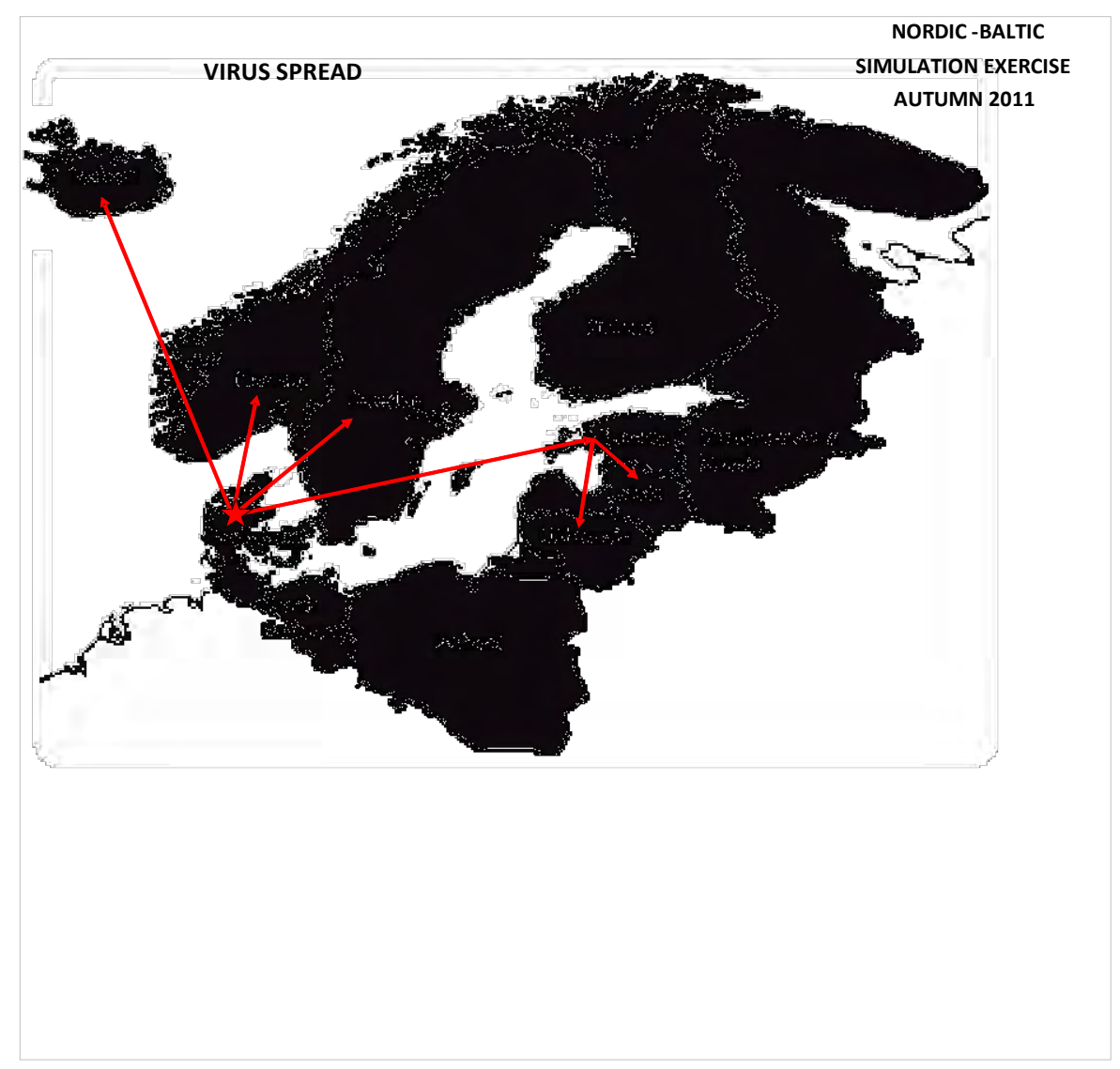

Figure 1. Virus spread.

\section{Exercise design}

Autumn 2011 was an inject-driven exercise. This included that the facilitating or directing staff (DISTAFF) ensured the flow of the activities of the exercise. Messages (injects) were sent to the exercise players using various communication means outlined in the national contingency plans adopted of the Nordic- Baltic countries. The exercise players were expected to respond to messages received from the DISTAFF within the framework of their contingency plan and transmit relevant information to the other players along with copies of the messages to the DISTAFF. The procedures made it possible for the DISTAFF to oversee the exercise operation and to intervene if deemed necessary. Guidelines for work to be carried out by the DISTAFF and templates for injects are listed in the PID. Each country prepared injects and all injects are listed in an annex to the PID. 


\section{Participants}

Representatives from the Central Veterinary Administrations of all Nordic-Baltic countries participated in the planning, implementation and evaluation of the exercise. The number of participants (players and DISTAFF) varied from country to country; but about 700 persons were involved, see table II.

Table II. Scope of the Nordic-Baltic ASF exercise "Autumn 2011"

\begin{tabular}{llllll}
\hline Country & Suspicions & Outbreaks & Farm visits & Persons involved & Livestock holdings involved \\
\hline Denmark & 3 on 11/10 & 3 on 11/10 & 6 & 50 & 3 \\
Estonia & 1 & 1 & None & $15-20$ & \\
Finland & 3 & None & None & $5-10$ & \\
Iceland & 3 & 3 & 3 & $11-15$ & 3 \\
Latvia & 1 & 1 & None & 50 & \\
Lithuania & 1 & 1 & & 30 & 1 \\
Norway & 5 & 4 P on 12/10 +1 S & None & 500 & 0 \\
\hline Sweden & 3 & 3 & None & 50 & \\
\hline
\end{tabular}

$\mathrm{P}=$ Primary; $\mathrm{S}=$ Secondary

\section{Implementation}

The exercise was well received by the players performing tasks designated to be carried out by the veterinary administrations and the livestock sector, respectively. All players responded with great enthusiasm to the exercise injects and it was by and large possible to maintain the prepared timed schedule.

Autumn 2011 operated to a great extend under the provisions of the African swine fever Council Directive 2002/60/EC (3). The provisions include that EU Member States shall create a permanently operational expert group to maintain the expertise needed to assist the veterinary administrations in ensuring disease preparedness. One country, Denmark, used the expert group to provide information on certain situations exposed to during the exercise. Some of the questions related to these situations were:

- What information can be provided with regard to the survival of ASF virus in soil at farm land with free roaming pigs?

- What are the recommendations for handling of outdoor areas used by infected pigs?

- What are the recommendations of the expert group with regard to a surveillance programme for swine fever in wild boar in Denmark?

- The Legislation calls for certain visits to farms situated in the $3 \mathrm{~km}$ protection zone and the $10 \mathrm{~km}$ surveillance zone to be established in the event of an ASF outbreak. Can the expert group recommend procedures to be applied during such visits? Would quarantine period be relevant?

\section{Evaluation}

The N-B VCG developed prior to the exercise a questionnaire as a tool to assist countries in evaluating the parts of the exercise related to Communication and to future training of personnel. The questionnaire is shown as a part of PID.

\section{Conclusions and recommendations}

All countries reported a successful implementation of the ASF simulation exercise and the applied exercise methodology was found very valuable for evaluating existing contingency plans and for further development of veterinary preparedness at local and central level. 
At the inter-Nordic-Baltic level it was observed that a better communication system should be established between the veterinary administrations of the Nordic Baltic region. A follow-up activity of the N-B VCG included the following recommendation:

It is recommended that a communication plan should be adopted for use between the veterinary administrations of Nordic and Baltic Countries during extraordinary events. This applies for examples to use of telephone conferences, text messages and various means of modern electronic meeting facilities. It could also include initiative to set up a meeting, agenda etc. The N-B VCG is fully aware of the communication through the European Commission during emergencies, but still wants to stress the value of a rapid and robust inter-Nordic-Baltic communication system during time of crisis.

With regard to National activities the number of tasks performed and number of veterinarians involved varied from country to country. Certain weak points in the National Contingency Plans were elucidated by the exercise in some countries and steps would be taken to improve plans where necessary.

It was noted that the previously conducted simulation exercises on Foot and Mouth Disease (4), Bluetongue (5) and West Nile Fever (6) by and large were considered full scale simulation exercises. It could be valuable to review the different types of exercises described in the literature such as drill, tabletop exercise, functional exercise, real-time alert exercise. 


\section{The Project Initiation Document}

Document Reference: PID 2010/11

Version: September 2011

Status: Final

Main Authors: Members of the Nordic-Baltic Veterinary Contingency Group

Time of simulation exercise: Week 41 (10 - 14 October 2011). Starting on Tuesday 11 October at 12:00 hours (Copenhagen time) and ending on Wednesday 12:00 hours (Copenhagen time)

Area of responsibility: Nordic-Baltic Veterinary Contingency Group.

Document stakeholders: See table III.

Table III. Document stakeholders

\begin{tabular}{|c|c|c|c|}
\hline Stakeholder: Country or Institution and Name & Contributor & Reviewer & Approver \\
\hline $\begin{array}{l}\text { Denmark } \\
\text { Camilla Brasch Andersen } \\
\text { Hanne M. Hansen }\end{array}$ & $\checkmark$ & $\checkmark$ & \\
\hline $\begin{array}{l}\text { Finland } \\
\text { Mia Kauremaa }\end{array}$ & $\checkmark$ & $\checkmark$ & \\
\hline $\begin{array}{l}\text { Estonia } \\
\text { Maarja Kristian }\end{array}$ & $\checkmark$ & $\checkmark$ & \\
\hline $\begin{array}{l}\text { Iceland } \\
\text { Audur Arnthorsdottir }\end{array}$ & $\checkmark$ & $\checkmark$ & \\
\hline $\begin{array}{l}\text { Latvia } \\
\text { Edvins Olsevskis }\end{array}$ & $\checkmark$ & $\checkmark$ & \\
\hline $\begin{array}{l}\text { Lithuania } \\
\text { Egidius Pumputis }\end{array}$ & $\checkmark$ & $\checkmark$ & \\
\hline $\begin{array}{l}\text { Norway } \\
\text { Siri Løtvedt }\end{array}$ & $\checkmark$ & $\checkmark$ & \\
\hline $\begin{array}{l}\text { Sweden } \\
\text { Suha Mohammad } \\
\text { Elisabet Lindal }\end{array}$ & $\checkmark$ & $\checkmark$ & \\
\hline $\begin{array}{l}\text { ADC-Consult } \\
\text { Jørgen Westergaard }\end{array}$ & $\checkmark$ & $\checkmark$ & \\
\hline N-B VCG & & & $\checkmark$ \\
\hline
\end{tabular}

\section{Background}

The Nordic Council of Ministers has focused on the importance of preparedness towards exotic animal diseases that might be a threat to this region of Europe.

With the objective to increase African swine fever preparedness, the Central veterinary Administrations of the Nordic and Baltic Countries intend to conduct a jointly and comprehensive ASF simulation exercise in the month of October, 2011. The exercise shall be prepared and carried out based on inputs from the Nordic-Baltic Veterinary Contingency Group (N-B VCG). 


\section{African swine fever}

African swine fever (ASF) is usually an acute, highly contagious, disease of domestic pigs (Sus domestica) characterised by widespread haemorrhages and a very high mortality. In areas where the disease is endemic in domestic pigs it tends to become sub-acute or chronic, with a much reduced mortality. Survivor animals remain carriers of the virus, which they periodically disseminate.

ASF was first recognised as a distinct disease in 1910 when domestic pigs were introduced into Kenya. Here the disease perpetuates in a sylvatic cycle primarily between warthogs (Phacochoerus) and argasid ticks (Ornithodorus spp) that inhabit their burrows. Warthogs, which are subclinical, infected, remain carriers for long periods.

Causative agent: ASF-virus is a DNA virus in the Asfaviridae Family; genus: Asfivirus

\section{Sources of virus}

- Blood, tissues, secretions and excretions of sick or dead animals

- Animals which have recovered from infections may become persistently infected, acting as virus carriers

- Soft ticks of the genus Ornithodorus

\section{Incubation period}

Usually $3-15$ days; acute form $3-4$ days.

\section{Transmission}

- Direct by contact between sick and healthy animals

- Indirect through (a) feeding of infected meat, (b) fomites including premises, vehicles, implements and clothes (c) biological vectors (soft ticks-Ornithodorus)

- Within tick vector: Transtadial, transovarial and sexual transmission occur

\section{Occurrence of ASF}

The disease has gained increased attention in Europe as an "emerging disease" among others because of outbreaks starting in 2007 in the Trans-Caucasian Countries. ASF has never been reported in the NordicBaltic countries.

\section{Occurrence of ASF in Europe}

The disease was from 1957 - 1994 endemic at the Iberian Peninsula and it has since 1978 occurred as an endemic disease in a limited location of Sardinia, Italy. The disease has furthermore occurred in Europe as shown below:

$1978-1981$ in Malta

1983 in Piedmont, Italy

1985 in Belgium

1986 in the Netherlands 
1999 in Portugal

In 2011 outbreaks were recorded in Georgia, Armenia, Azerbaijan and Russia

\section{Legislation and related documents}

ASF is notifiable in EU in accordance with the provisions of Council Directive 82/894/EEC of 21 December 1982 on the notification of animal diseases within the Community

The legal provisions related to control and eradication measures are in particular given in:

a) Council Directive 2002/60/EC of 27 June 2002 laying down specific provisions for the control of African swine fever and amending Directive 92/119/EEC as regards Teschen disease and African swine fever

b) Commission Decision 2003/422/EC of 26 May 2003 approving an African swine fever diagnostic manual

c) Council Directive 90/425/EEC of 26 June 1990 concerning veterinary and zootechnical checks applicable in intra- Community trade in certain live animals and products with a view to the completion of the internal market Related documents

Documents with valuable information on aspects of ASF contingency planning include:

- World Organisation for Animal Health (2009) - Terrestrial Animal health Code, OIE, Paris

- World Organisation for Animal Health (2008) - Manual of Diagnostic Tests and Vaccines for terrestrial Animals, OIE, Paris

- -National contingency plans for African swine fever (ASF)

- -Scientific Opinion on African swine fever; EFSA Panel on Animal Health and Welfare (AHAW) published on 19 April 2010.

- -FAO Animal Health Manual: RECOGNIZING AFRICAN SWINE FEVER. A field manual. 


\section{The Project Definition}

\section{Aim and objectives}

The purpose of the N-B VCG Emergency Preparedness Exercise is to enhance joint emergency preparedness among veterinary administrations in the Nordic and Baltic Countries and to assist in the understanding of roles and responsibilities in the event of African swine fever outbreaks.

The objectives at inter-Nordic-Baltic level are:

- To train the rapidly exchange of information between relevant persons in the Nordic and Baltic countries

- To make use of the Memorandum of Understanding on Nordic-Baltic Animal Health Emergency Reserve. The memorandum shall be used of at least at two occasions

- To explore the potential for exchange of resources (specified in the catalogue-delete) of mobile equipment

At National level the objectives include:

- To activate the National disease control centre

- To activate one or several Local Disease Control Centre(s)

- To carry out pig trace-back activities on national movements and on movements related to import and export of animals

- To test the capability of depopulating infected farms and in-contact farms

- To test procedures for disposal of carcasses from infected herds

The specific objectives adopted by individual countries are shown in Annex 1.

\section{International injects}

The AUTUMN 2011 simulation exercise will have a number of injects at Nordic-Baltic level and the proposed injects are shown in Annex 1.

A template for international injects is shown in annex 6 .

An Excel spreadsheet has been prepared for listing of international injects.

\section{Exclusions}

The simulation exercise involves the 8 Nordic and Baltic countries with regard to testing communication links and cooperation related to the control and eradication of African swine fever.

National exercise elements must not compromise the overall aim and objectives.

The elements in the exercises concerning handling of animals such as depopulation of herds will be simulated while clinical examinations of animals and collection of specimens for laboratory examination may take place. 


\section{Deliverables and outcomes}

The main output of the exercise at the international level is to examine and evaluate the communication between the Nordic-Baltic countries.

Inter Nordic-Baltic activities will include trans-border communication between the Nordic-Baltic countries at national administrative level/CVO-level. The important issue is to test and define the contact points and their possible alternatives on the national/CVO-level.

The names and contact points of the Chief Veterinary Officers in the Nordic and Baltic countries are given in Annex 5

Secondary, but very important outputs are to observe and evaluate the response and compliance to the national established objectives for the ASF simulation exercise.

The observations made and evaluation will be recorded.

\section{Interfaces/dependencies/partners}

The exercise will examine the communication between the CVOs in the Nordic and Baltic countries.

The veterinary administrations in Nordic and Baltic countries can be parts of the exercise e.g. as participants in a national response cell.

The Nordic-Baltic Veterinary Contingency Group shall draw-up the scenario and develop the exercise injects. The members will be the directing staff (Distaff) and be in close contact during the exercise.

\section{Finance and communication plans}

\section{Finance}

Each country will take care of expenses related to the simulation exercise. However, there is a possibility for a few young veterinarians to participate as observers during the exercise outside their own country. The Nordic Council, through the N-B VCG, will cover travel expenses (flights), but not the cost for accommodation and living.

\section{Communication}

Inter Nordic-Baltic communications plan and National communication plans to be developed.

An initial draft announcement is shown in annex 4, section A. The draft announcement provides information applicable to all 8 countries and suggests specific information to be provided on issues relevant for individual countries. A draft notification to the OIE and the EU is shown in annex 4, section $B$.

\section{Scenarios}

The first recorded outbreak of ASF shall occur in Denmark based on the simulated outbreak described in annex 2. The Danish CVO will announce clinical cases of (African) swine fever; ASF was confirmed by detection of virus genome by the polymerase chain reaction - PCR techniques and by serology.

Details of scenarios prepared by individual countries are given in annex 3 . 


\section{Guidelines for directing staff}

During the exercise the members of the Nordic Baltic Veterinary Contingency Group works as directing staff (distaff). The distaffs know the scenario and the time of the events and have different tasks during the exercise:

- Monitor the progress of the exercise and intervene if necessary

- Coordinate the progress of the exercise

- Draw up a preliminary exercise report for each country

Injects shall be included in an excel spreadsheet which shows the events of the exercise.

It is important that the distaff make sure that the players acknowledge the receipt of all messages and all emails are sent cc. to the distaff mail address prepared for the exercise.

The distaffs draw up a preliminary report based on observations during the exercise.

\section{Success criteria and evaluation}

The success criteria of the simulation exercise include that:

- The exercise provides the participants with a good opportunity to train their ability to exchange information within the Nordic -Baltic countries during emergency situations

- Messages reach the persons for whom they are intended without delay

- The Memorandum of Understanding on a Nordic Animal Health Emergency Reserve is being tested

- The potential exchange of mobile equipment between countries is being explored

- The implementation of the simulation exercise by and large adhere to the scheduled timetable

\section{Evaluation}

Copies of all international communication shall from the individual countries be forwarded to the mailbox: NBWNF@fvst.dk. The communications shall assist in the evaluation of the exercise.

No external evaluator shall be employed but evaluations forms shown in annex 7 shall be used.

\section{Acknowledgements}

The organizers of the African swine fever simulation exercise "Autumn 20111" would like to express their thanks to the Nordic Council of Ministers for the political support and the financial support made available for the preparation, implementation and valuation of the exercise. 


\section{References}

1. Westergaard, J.M. (2008). Preparedness for Major OIE-listed Epidemics: Implementation of Simulation Exercises. Zoonoses Public Health. 55, $37-41$.

2. Westergaard, J.M., 2012: Information obtained from Ministry of Economic Affairs, Agriculture and Innovation in the Netherlands, and the Department for Environment, Food and Rural Affairs (Defra) in the United Kingdom.

3. European Union (2002) - Council Directive 2002/60/EC of 27 June 2002 laying down specific provisions for the control of African swine fever and amending Directive 92/119/EEC as regards Teschen disease and African swine fever. Off. J. Eur. Communities. L 192, 20.7.2002, p. 27.

4. Westergaard, J.M., C.B. Andersen and S. Mortensen. (2008). A foot and mouth disease simulation exercise involving the five Nordic countries. Rev. sci. tech. Off. Int. Epiz.,27 (3), 751 -758.

5. Nordic-Baltic Veterinary Contingency Group. (2008). Nordic-Baltic Bluetongue Simulation Exercise "HOT AIR".

6. Nordic-Baltic Veterinary Contingency Group. (2009). Exercise SPRING, Nordic-Baltic West Nile Fever Exercise 2009. 


\section{Annex 1}

\section{Proposed objectives for a national African swine fever simulation exercise in the Baltic and Nordic countries}

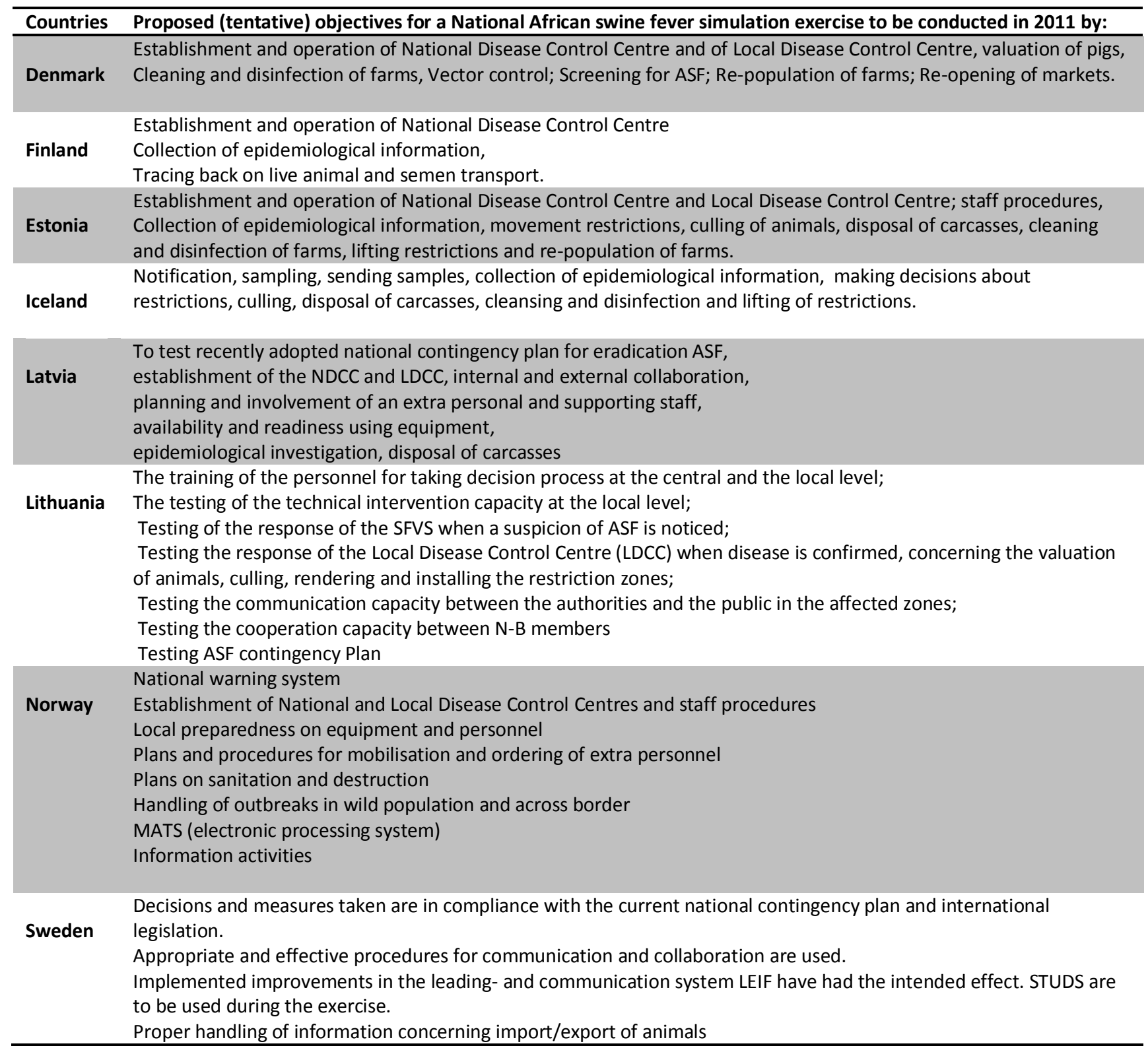




\title{
Proposed international injects for an African swine fever simulation exercise to be conducted in October 2011 in the Baltic and Nordic countries
}

\author{
Countries Proposed suggestions for international injects \\ 1) Report on the SF suspicions in Denmark based on the scenario shown in annex 2; reports to all Nordic-Baltic \\ Denmark countries \\ 2) Report on the recorded ASF outbreak in Denmark \\ 3) Make contact to the Baltic countries and Sweden for information on experiences gained in recent years with \\ regard to surveillance of the wild boar populations, localization of specific populations, control and capture \\ of wild boar etc. \\ 4) Potential exchange of equipment (Hurricane) \\ Finland 1) Live pigs (breeding animals) from ZZ-farm in Denmark were transported to QQ-farm in Finland on October \\ 3th. On October $11^{\text {th }}$ request for information concerning the ZZ-farm, is the farm one of the suspects farm or \\ in the restricted area? \\ 2) Live pigs (breeding animals) from $X X$-farm in Norway were transported to $Y Y$-farm in Finland on October \\ 7 th. On October $11^{\text {th }}$ request for information concerning the XX-farm, is the farm one of the suspected \\ farms or in the restriction area?
}

\begin{tabular}{lll}
\multirow{3}{*}{ Estonia } & 1) & To Denmark: Question about export of meat during the last 5 weeks- use real data \\
& 2) & To Latvia: Information about transportation of live pigs \\
& 3) & To: Lithuania: Information about live pigs. \\
Iceland & 1) & Communication between the laboratory in Iceland and the laboratory at Lindholm, Denmark.
\end{tabular}

1) $\begin{aligned} & \text { To Denmark: To provide information to CVO that DD pig farm owner (Danish nationality) has his holidays } \\ & \text { (from 10th - 22nd of September) in Denmark, probably with friends and business partners who own pig } \\ & \text { farms. }\end{aligned}$
$\begin{array}{ll}\text { 2) } \\ \text { To Lithuania: request to organise the epidemiological investigation for all "Beautiful Piggy's show" (held on } \\ \text { 24th of September in LT) participants - pigs from several countries and herds including DD farm in Latvia }\end{array}$
3) To Finland: Request for assistance by five practicing veterinarians to combat ASF in LV.
Lithuania
1) To Sweden: Information about farm worker who visited his parents farm in Lithuania $4-9$ October
2) To Denmark: Request for experts to help in fighting outbreak

1) To Denmark: Where has the meat from the infected premise been sold? Maybe we can target our
information to Norwegian buyers, if all is sold in one place.
2) To Sweden: the wild boar with ASP found near the border, may have brought the infection to Sweden. How
do we handle an outbreak concerning two countries?
3) To Iceland: an Icelandic veterinarian who has been on the infected farm in Klepp has gone home to Iceland
to visit family on a pig farm.
4) To Latvia: a group of Latvian workers from several farms in Rogaland have gone home on holiday.
4weden
1) To Denmark: Request for information concerning transport of pigs, from the island of Bornholm through
Sweden to Denmark, during the last 3 weeks. Details asked for: transport route, dates and time, how many
pigs, when and where to etc.

2) To Estonia: Pigs (breeding animals) from ZZ-farm in Sweden to EE-farm in Estonia. ZZ-farm is a contact herd to one of the suspected herds

3) To Norway: Anton from Sweden works as waiter at a restaurant in Oslo. During the weekend 7-9/10 he has been visiting his parents pig farm in Skåne. He went back to Oslo 10/10 to work evening shift. (He brings pork for private use, but since he goes straight from train to work he keeps the pork in a refrigerator at the restaurant

4) To Finland: Pigs from NN-farm in Sweden were transported to FF-farm in Finland on October 6. NN farm is situated in the restriction area ( $10 \mathrm{~km}$ zone) to a farm with suspicion of ASF. The inject is send as a fax, a filled in form from Traces (technical problems in Traces)

5) To Latvia: Can you help us with 5 practicing veterinarians to assist in the combat of ASF in Sweden 


\section{Annex 2}

\section{The start of "AUTUMN 2011" by a simulated ASF outbreak in Denmark}

\begin{tabular}{|c|c|}
\hline \multicolumn{2}{|l|}{ Date - 2011} \\
\hline September 17 & $\begin{array}{l}\text { A break-down reported of the ventilation system at a farm belonging to Mr. MM. } \\
\text { Temperature at mid-day } 30 \mathrm{C} \\
\text { Mr. MM owns } 3 \text { Farms (A, B and C) Break-down on farm C. } \\
\text { Farm A: } 850 \text { sows and piglets } \\
\text { Farm B: Weaners and fattening pigs ( } 5000) \\
\text { Farm C: } 80 \text { Fatteners }\end{array}$ \\
\hline Sunday 18 & $\begin{array}{l}\text { Repair completed by a firm with great experiences in building and maintaining ventilation systems in barns } \\
\text { throughout Europe }\end{array}$ \\
\hline \multicolumn{2}{|r|}{ (1) } \\
\hline \multicolumn{2}{|l|}{20} \\
\hline \multicolumn{2}{|l|}{21} \\
\hline \multicolumn{2}{|l|}{22} \\
\hline \multicolumn{2}{|l|}{23} \\
\hline \multicolumn{2}{|l|}{24} \\
\hline \multicolumn{2}{|l|}{ Sunday 25} \\
\hline 26 & $\begin{array}{l}\text { Stable in Farm C emptied and all } 80 \text { pigs send for slaughter in town X. } \\
\text { Temperature during transport } 29 \text { C } \\
\text { Two (2) pigs dead on the arrival at the slaughterhouse. Epidemiological investigation revealed: } \\
\text { No illness in the pigs on Farm A and B } \\
\text { Farm C had until } 20 \text { September had cases of Swine Erysipelas ( Erysipelothrix rhusiopathiae infection) - Diamond } \\
\text { skin disease } \\
\text { The driver of the truck had due to illness been replaced just before departure with a driver without experience in } \\
\text { driving trucks with animals } \\
\text { Conclusion: Since no illness on the farm A, B and C) the } 2 \text { deaths were most like caused by hot weather conditions, } \\
\text { an un-experienced driver and perhaps complications after the Erysipelothrix infection. }\end{array}$ \\
\hline \multicolumn{2}{|r|}{ 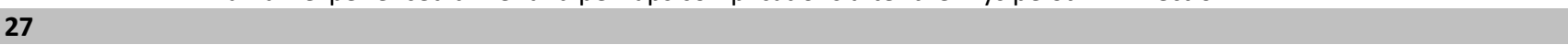 } \\
\hline \multicolumn{2}{|l|}{28} \\
\hline \multicolumn{2}{|l|}{29} \\
\hline \multicolumn{2}{|l|}{30} \\
\hline \multicolumn{2}{|l|}{ October 1} \\
\hline \multicolumn{2}{|l|}{ Sunday 2} \\
\hline \multicolumn{2}{|l|}{3} \\
\hline 4 & Pigs exported from stable B \\
\hline \multicolumn{2}{|r|}{ (2) } \\
\hline 6 & Some pigs in Stable B are sick \\
\hline 7 & Veterinarian called suspicion of Erysipelothrix infection or Porcine Dermatitis and Nephropathy (PDNS) \\
\hline \multicolumn{2}{|r|}{ 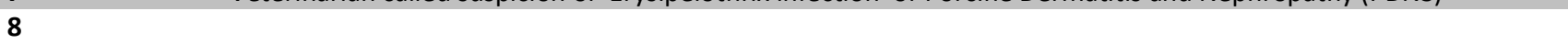 } \\
\hline Sunday 9 & No response to treatment with antibiotics - death $3 \%$ of young pigs \\
\hline 10 & $5 \%$ of young pigs dead. Exotic disease considered \\
\hline 11 & ASF confirmed \\
\hline
\end{tabular}




\section{Annex 3}

\section{Information on scenarios prepared by individual in the Nordic-Baltic region}

\section{Denmark}

The exercise in Denmark will start in the morning 11. October with three suspicions of ASF, and will continue until 13 of October, after ending the Nordic-Baltic parts of the exercise on 12 October 12 o'clock.

The situation in Denmark starts as described in the PID as "Start of AUTUM 2011".

In the middle of September 2011 a pig farm in Jutland has a breakdown in the ventilation system. Reparation of the system is completed by a firm operation throughout all Europe.

10 days later pigs are found dead on the arrival at the slaughterhouse, but no sign of any specific disease problems at the farm. By the beginning of October unspecific symptoms starts in the stable with fattening pigs, from which pigs are exported a few days earlier. The pigs are treated without any response to treatment.

By the 10 of October ASF are suspected in this farm and two other farms (who also had used the same ventilation firm) and by the 11 . October outbreaks of ASF are confirmed in all three farms.

On 11 October Denmark will inform the other Nordic and Baltic countries about the three suspicions of ASF in the morning ( 9 o'clock), and confirm the outbreaks about 12 o'clock.

It is possible that infected meat from the first farm as well as live pigs during the incubation period, are exported to other Nordic or Baltic countries.

In the exercise the Danish regional veterinary offices will focus on the suspicions of ASF on 11 October and planning on killing, cleaning and disinfection on 12 October.

On 13 October the Danish part of the exercise will jump in time which makes it possible to focus on planning of screening activities, with the intention to lift the zones.

The central part of the Danish veterinary administration will on the first two days participate in the NordicBaltic part of the exercise with focus on crises organisation, communication and information. On 12 October they will start preparation for lifting of the zones the last day.

\section{Estonia}

On September 29th a transport vehicle transports pigs for slaughter into slaughterhouse in Leningrad oblast, near restriction area with suspicion of ASF. African swine fever has been recently diagnosed in Russia. In the evening that vehicle (empty) enters Estonia through board inspection post in Narva. The driver decides to spend the night at his friends' place that occasionally transports pigs. In the morning the driver continues his journey to farm A where he helps to catch fattening pigs uploads and transports them into farm B. In farm B the driver helps to download pigs and drove them into pens. The vehicle is thoroughly cleaned and disinfected in farm B. 
On Farm A the worker notices the first sick pig on October 6th but thinks that it is irrelevant and does not inform owner or veterinarian. During the next few days more pigs get ill and on 8th of October the veterinarian is informed who starts treatment with antibiotics but there is no response. The diagnosis will be confirmed on October 11th.

On 10th of October 68 pigs have been transported to Latvia for slaughter from Farm A.

Inject: inform Latvian CVO/competent authority about transportation by e-mail. Inform Latvia and Finland about ASF.

On Farm B the sick pig is noticed on 12th of October, treatment with antibiotics but no response.

During the next day's more pigs get sick.

A citizen of Norway visits his parents near Klepp in Rogaland County on 5th - 7th of October and brings back to Estonia a couple of kilograms of raw meat bought from small pig farm near Klepp. Back in Estonia, on 9th of October, he is invited to small barbeque at neighbours home. He puts a small portion of meat into refrigerator into marinade and takes the rest of the meat to barbeque. Neighbours have one mini pig that moves freely among guests in fenced backyard. Among guests there is a family from Lithuania who keeps pigs. Lithuanian family goes back to Lithuania on 9th of October. On the 10th of October the owner of the mini pig calls to veterinarian and on 11th of October the diagnosis is confirmed.

inject: inform Lithuanian CVO/competent authority about Estonian mini pig in with diagnose of ASF and that Lithuanian pig farmers were visiting the owners of above mentioned mini pig (e-mail); inform CVO/competent authority of Denmark about infected pork and its origin.

\section{Finland}

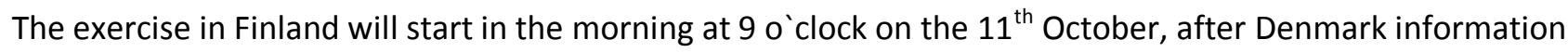
about suspicion on ASF in Denmark. The national exercise will end at same as international exercise, on the $12^{\text {th }}$ of October at $12 o^{\prime}$ clock.

About 5-10 persons will participate the exercise in Evira and 1 person will participate in ministry of agriculture and forestry. The national disease control centre will be activated and the main focus will be international communication and information, tracing back animal transport and epidemiological information. No on-farm visits will be conducted.

In the exercise; from the beginning of October there have been normal live animal transports from Denmark (the $\left.3^{\text {rd }}\right)$, Norway $\left(7^{\text {th }}\right)$ and Sweden $\left(6^{\text {th) }}\right.$ to Finland.

In the morning of $11^{\text {th }}$ of October there will be no clinical suspicion of ASF in Finland. After the information about suspicions and confirmations of ASF outbreaks in all these countries, from where live pigs have been transported to Finland, the destination farms and possible contact farms and animals will be clinically inspected and tested. There won't be a confirmed ASF outbreak in Finland during the exercise. 


\section{Iceland}

\section{Objective}

The objective of the Icelandic national part of the exercise is to drill a part of the specialists and the staff at MAST and the official laboratory at Keldur in the initial steps of response to ASF, which includes: Notifications, sampling, sending samples, collection of epidemiological information, making decisions about restrictions, culling, disposal of carcasses, cleansing and disinfection and lifting of restrictions. It's important to notice that of the normal initial steps of response, tracing of the infection is excluded from the exercise.

\section{Scenario}

On the $11^{\text {th }}$ of October there will be three farms with clinical signs of ASF, one in North Iceland, one in the South and one in the Reykjavik area. The route of introduction to the country and spread of the virus within the country is unknown (and will remain unknown).

\section{Participants}

Participants of the exercise will be three district veterinary officers, three veterinary inspectors, two veterinary specialists at MAST, the CVO, the laboratory staff and distaff.

\section{Execution}

The distaff will call the DVOs at 08:00 on Tuesday the $11^{\text {th }}$ of October and pretend to be private practicing veterinarians and tell them about suspect symptoms in pigs on farms in their districts. The DVOs are supposed to respond by activating the contingency plan for foreign animal diseases and follow the procedure of the plan as regards: Notification, examination of the pigs, putting on restrictions, collection of epidemiological information, sampling and sending samples to the lab, as well as making plans for culling, cleansing/disinfection and disposal of carcasses. The veterinary specialists at MAST and the CVO are also supposed to respond regarding to the contingency plan which includes notification, guidance and decision making. The lab is supposed to respond by contacting the lab at Lindholm in Denmark, prepare the samples for shipping and send them to Denmark. Analyses of the samples and a reception of results are also a part of the exercise.

\section{Latvia}

- The main focus will be to test the chain of command and to convene the National crisis control centre (NCCC);

- The central office of Food and Veterinary Service (FVS), at least three regional offices of FVS, Ministry of Agriculture and representatives from other ministries (NCCC) will be involved in exercise; Number of participants $\sim 50$ persons;

- There are no practical activities (sampling, clinical examination, killing etc.) planed during the exercise, except epidemiological investigation.

For overall information there are 2206 pig holdings and totally with 321087 pigs in them in Latvia. The index farm (DD) is real farm located in the midland of Latvia, near Lithuanian border. It is a pig breeding farm with boars, sows, piglets and wieners, in total 12600 pigs.

The DD farm has a regular live pig trade for slaughter to Russia provided by the Lithuanian trade company. 
The DD farm owner is Danish man and on the territory of Latvia he has 3 pig farms. One of them - PP farm is breeding farm (sows and piglets) which regularly provides other 2 fattening farms (SS and DD) with fattening piglets. Last 2 weeks (from 10th - 22nd September) farmer was on holidays in Denmark. During the owner holidays animals were handled by the local workers.

Last month (mid of September to mid of October) several pigs were found dead without any typical clinical signs of ASF.

The 2 farms (SS and PP) are located approximate $150 \mathrm{~km}$ North East from the DD farm. There are regular pig movements and other type of collaboration between them.

On 24th of September there were a "Beautiful Piggy's show "- the international pig breeds show held in Lithuania, with participation 9 pigs from DD farm and 12 pigs from SS farm. Afterwards, on 28th September 13 young sows and one boar from DD farm were sold to Estonia for breeding purposes.

On 1st October the pregnant sow is found sick showing general signs disease. A veterinarian observes the difficulty of breathing and has a suspicion on bronchopneumonia. Health status of the animal did not improve after the use of antibiotics.

During the farrowing - 7th of October farmer found 15 piglets, 10 of them were born dead, and during the next few days all piglets and sow were found dead. There was no evidence of ASF during post mortem examination.

There are no typical clinical signs observed on 9-10th of October but the veterinarian found dead several weaners. Veterinarian took samples for laboratory testing to several diseases (salmonellas, pasteurellosis) and put a special note to exclude CSF and ASF.

12th of October there is a call from National reference laboratory with a confirmed ASF!

During the epidemiological investigation it is found that on the 17th of September there were the wedding celebration held $5 \mathrm{~km}$ from the index farm DD, with the participation of local worker (who handled the pigs in DD farm). Some of the wedding guests were from the Russia, Tversk region. They brought from Russia meal (smoked pig meat) with them as a present. After the wedding the unused smoked meat was divided between the relatives and one of them brought this meat in sandwich and took it to the DD farm during the duties there.

\section{Lithuania}

\section{Organization}

About 15 persons at the State food and veterinary service will participate, including CVO, and the persons dealing with the notification systems, in charge of producing maps, keeping the register, etc. Some types of on-farm activities might be undertaken. There will no participation from any other institution.

Seven specialists from the central disease control centre (CDCC) will participate in the training and seven inspectors will come to the Local disease control centre (LDCC). They will stay in the Radviliskis district of Siauliai County, which is in the central part of Lithuania. They will receive all the information from CDCC just 
in the morning of 11 October. By now all LDCC have received the information that at this time all centres must be ready for action.

Two persons from the CDCC will act as the coordinators: Egidijus Pumputis and Mindaugas Kašinskas form SFVS.

Preliminary schedule: the exercise will start October 9.00 and might continue until 17.00 ,

On October 12 the exercise will continue between 8:00 and around 14.00.

\section{Scenario}

- 10-10-2011 increased mortality, possible feeding toxicosis or viral diseases in farm of company ZUB „Grazioniu bekonas"..

- 10-10-2011 owner informed territorial State Food and Veterinary Service of Radviliskis district about increased mortality of pigs.

- 10-10-2011 samples were taken and 11-05-2011 tested positive in National Food and Veterinary Risk Assessment Institute (hereafter - NFVRAI) against African swine fever. All the samples were investigated by RT-PCR. Pigs were analyzed post mortem.

- 11-10-2011 Lithuania confirms the Outbreak of African swine fever and informs the Nordic-Baltic countries.

- 11-10-2011 Request to Denmark and Iceland for experts to help in combating the outbreak of ASF.

\section{Chronology of disease}

- Increased mortality in pig farm of company ZUB "Grazioniu bekonas" Radviliskis district of Siauliai county.

- All pigs are reared and fattened in the same pig farm area (Radviliskis) but every week pigs are exported to Russian Federation for slaughter in the slaughterhouse of Leningrad oblast.

- After investigation it was detected that the owner of the farm has a son who is working in Sweden in a pig farm and who visited his parents' pig farm in Lithuania on $4-9$ October. It's possible that the son has taken some home-made products from pig meet with him.

\section{Norway}

We previously agreed that the AFV virus should be introduced in Norway by import of infected meat from Denmark. Because of the relatively short time span from the onset of the outbreak in Denmark to the exercise, we want to add one additional contact to Denmark to create a credible larger outbreak. In addition to the meat track, we also want the international ventilation firm to go on a round trip for service assignments in Norway.

The swine industry is regionalized in our country, so to create an outbreak in several regions in such a short time, we need some extra sources of infection.

On September 22nd the ventilation firm arrives on a pig farm in Klepp in Rogaland County to do maintenance work on the ventilation system. On this farm the owner notices the first sick pig on October 1st. The owner thinks the pig has a heart condition, and kills it and sends it to a rendering plant nearby. The next week more pigs are sick, a veterinarian is called and suspects infection with Erysipelothrix, but there is 
no response to treatment with antibiotics. Like in Denmark, the diagnosis will be confirmed on October 11th.

The area around Klepp is the densest pig farming area in Norway, and the infection will already have spread to several other farms at the time of the confirmed diagnosis.

The ventilation firm started working in a pig farm in Trøndelag on the 26th of September, and this farm and a neighbouring farm will be infected. The diagnosis will be confirmed on the 12th of October.

The ventilation firm later goes to a farm in the county of Hedmark, but this farm will not be infected.

The meat track will create an additional outbreak in the community of Aremark near the Swedish border. A dead wild boar is found on October 9th near a camp with a barbeque popular with foreign RV's. The source of the infection will be raw meat from Denmark. Norway has a surveillance program for wild boars, and the boar is sent to the National Veterinary Institute for examination, that takes place on the 11th of October. Later on a pig farm, who keeps pigs outdoors in the same area, is found to be infected. The Norwegian wild boars in Aremark have close contact with the Swedish wild boar population.

We will also put in some movement of mini pigs from infected areas to other counties in Norway, to create some activity there.

Norway will have three primary outbreaks with a secondary outbreak near two of them, and a large scale outbreak in Rogaland.

No on-farm activities will be conducted.

The exercise will engage about one third of the employees in the NFSA at the Head Office and in all regions and districts, about 500 persons. We have contact with the National Veterinary Institute and the stake holders, and they contribute to the planning of the exercise, but their level of participation has not yet been decided.

\section{Sweden}

\section{Organization}

About 40 persons at the Board of Agriculture will participate, including persons handling control measures and tracing, chief of staff, CVO, persons dealing with international contacts and notification systems, the function with knowledge in geographical information system and producing of maps, the register function etc. The entire crisis organisation will not be activated during the exercise.

No on-farm activities will be conducted.

There will not be any participation from other Swedish authorities except the National Veterinary Institute which means that Sweden might have difficulties to reply to inject concerning food questions etc.

Two veterinarians from the external epiteam will play the Local disease control centre (OLC). They will be in the same building as the rest of the crisis organisation but in a separate room. They will not be localised in a region or district. 
Two persons will act as the counter play, Joakim and one member from the epiteam. They will play some of the injects together with the distaff.

Directing staff are Suha, a colleague from our department Karin Eliasson and Joakim.

Preliminary time schedule: the exercise will start March 11 at 12.00 and might continue until $18-19.00$ in the evening.

On October 12 the exercise will continue between 8:00 and around 16.00.

\section{Scenario}

We plan to carry through a limited exercise on farm level in Sweden. We plan 3 infected farms. The infected farms will be in the south of Sweden, in the county Skåne

The infection is introduced into Sweden by pork/pork products/swill. 30/9 passengers from the ferry Helsingoer - Helsingborg travels north from Helsingborg. After a short drive they stop at a lay-by and throw away their litter, including swill, at the roadside. Farm A-se is infected $1 / 10$. This farm is an ecological farm with sows and piglets. The pigs have access of staying outdoors all year around. The owner of the farm A-SE also breeds pigs (conventional breeding, not ecological) at another farm (C-SE), at about $20 \mathrm{~km}$ distance. The infection will spread from either of these farms by selling of infected animals to one farm (B-SE) in the south of Skåne.

Farm B-se is maybe situated near the E-route between Malmö and Ystad. Danish pigs are sometimes transported (transit) on this route from/to Denmark and the Danish island Bornholm outside the Swedish coast. We would like to raise this issue to the participants.

After the first inject from Denmark we plan fairly soon to have a national inject describing a laboratory result positive for ASF from farm A-se. This farm has been sampled with no specific suspicion (some pigs have died) and several tests have been done after autopsy 10/10. Sweden has previously accomplished a number of start-up exercises and in this exercise we prefer to start a bit further into the events. Another advantage by having a confirmed diagnosis in the beginning of the exercise is to imply an incentive to start up an OLC-function earlier in the exercise.

Sweden also has to deal with the infected wild boar in Norway at the border to Sweden, county of Värmland. 


\section{Annex 4 - Announcements}

\section{Announcement of "Autumn 2011"}

\section{The Nordic-Baltic Region increases animal disease preparedness}

African swine fever is a highly contagious viral disease of pigs and with a very high mortality. The disease has gained increased attention in Europe amongst pig producers and veterinarians as an "emerging disease" since outbreaks was confirmed in 2007 in the Trans-Caucasian Countries. Since 2007 the disease spread rapidly in the domestic pig and wild boar populations in Georgia, Armenia and Azerbaijan. Outbreaks have also been recorded in Russia; but never in the Nordic-Baltic Countries.

The importance of preparedness towards exotic animal diseases that might be a threat to the Nordic and Baltic countries has been recognized by the Nordic Council of Ministers, and the Council supports close cooperation between the national veterinary administrations on disease protection and control measures. With the aim of enhancing joint emergency preparedness a Nordic-Baltic simulation exercise will be carried out in October 2011. The exercise will focus on simulated outbreaks of African swine fever. Each of the eight countries will during the exercise implement disease control measures addressed to eradicate the disease on their own territory and measures important for disease control at inter-Nordic-Baltic level.

In (name of country) the African swine fever simulation exercise will have focus on It will involve ..... and it will take place from ....

Further information may be obtained from ..... Name, and/ or email address and/or phone number.

\section{Announcement to OIE}

Dear Dr. Bernard Vallat,

This is to inform you that the Nordic and Baltic Countries - Denmark, Finland, Estonia, Iceland, Latvia, Lithuania, Norway and Sweden - will jointly conduct a simulation exercise on African swine fever. The exercise is called AUTUMN 2011 and it will take place from 10-14 October 2011.

The objectives at inter-Nordic - Baltic level include to train rapidly exchange of information between relevant person in the Nordic and Baltic countries and to explore the exchange of resources within the areas of personnel and equipment. At National level the objectives include activation of National disease Control Centres, Local Disease Control Centres, tracing of movements, depopulation of infected herds and disposal of carcasses.

On behalf of the Nordic Baltic Veterinary Contingency Group

Dr. --

\section{Announcement to the European Commission}

Very similar to the announcement to OIE 


\section{Annex 5 - Contact information \\ Contact information to the Chief Veterinary Officers (CVO) in the Baltic and Nordic countries}

\begin{tabular}{|c|c|c|c|}
\hline Country & Name of CVO & Telephone & E-mail \\
\hline Denmark & Per Henriksen & 004572276620 & 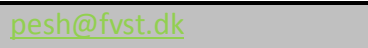 \\
\hline Finland & $\begin{array}{l}\text { Deputy CVO } \\
\text { Riitta Heinonen } \\
\text { (Contributor } \\
\text { Katri Levonen) }\end{array}$ & +358407233887 & katri.levonen@mmm.fi \\
\hline Estonia & Ago Pärtel & +3725035747 & \\
\hline Iceland & Halldor Runolfsson & $\begin{array}{l}\text { +3545304800 } \\
\text { +3548956265 }\end{array}$ & halldor.runolfsson@mast.is \\
\hline Latvia & Māris Balodis & $\begin{array}{l}+37167095230 \\
+37129264436\end{array}$ & maris \\
\hline Lithuania & Jonas Milius & +370 2404361 & vvt@vd.It \\
\hline Norway & Keren Bar-Yaacov & $\begin{array}{l}+4791300351 \\
+4723216840\end{array}$ & kebay@mattilsynet.no \\
\hline Sweden & $\begin{array}{l}\text { (Leif Denneberg) } \\
\text { Not available 11 - } 12 \\
\text { Oct.2011 } \\
\text { Bengt Larsson }\end{array}$ & $\begin{array}{l}+4636155810 \\
+46706452768 \\
+46702903753\end{array}$ & CVO@jordbruksverket.se \\
\hline
\end{tabular}


Annex 6 - Inject templates

INJECT template - blank

\begin{tabular}{|c|c|c|c|}
\hline Date & Time: & & File: \\
\hline From: & & On behalf of: & \\
\hline Recipient: & & & \\
\hline Title: & & & \\
\hline Inject message: & & & \\
\hline Communication means: & & & \\
\hline E-mail & & & \\
\hline By hand & & & \\
\hline Purpose & & & \\
\hline Expected reaction: & & & \\
\hline Observed reaction: & & & \\
\hline Comments to DISTAFF: & & & \\
\hline
\end{tabular}




\section{Example of INJECT prepared for "Autumn 2011": \\ INJECT nr 9}

\begin{tabular}{|c|c|c|c|c|c|}
\hline Date & 11.10 .2011 & Time: & $\begin{array}{l}13: 15(\mathrm{FIN} \\
14: 15)\end{array}$ & File: & Inject nr 9 \\
\hline From: & \multicolumn{2}{|l|}{ CVO Finland } & On behalf of: & & \\
\hline Recipient: & \multicolumn{5}{|l|}{ CVO Norway } \\
\hline Title: & \multicolumn{5}{|c|}{ Request for information concerning export of live pigs from Norway to Finland } \\
\hline Inject message: & \multicolumn{5}{|c|}{$\begin{array}{l}\text { Request for information concerning Peder Slotnæs' farm, is the farm under } \\
\text { restrictions for ASF? } \\
\text { EXERCISE: } \\
\text { CVO in Norway have informed other countries about the confirmed outbreak of } \\
\text { ASF in Norway. } \\
\text { Live pigs (breeding animals) from Peder Slotnæs } \\
\text { ( } 2350 \text { Nes H) in Norway were transported to farm owned by Jorma Vähä-Touru, } \\
31650 \text { Venäjänkangas in Finland on October 7th. }\end{array}$} \\
\hline $\begin{array}{l}\text { Communication means: } \\
\text { E-mail }\end{array}$ & \multicolumn{5}{|c|}{$\begin{array}{l}\text { E-mail to CVO Norwaykebay@mattilsynet.no } \\
\text { (copy to exercise mailbox NBWNF@fvst.dk and kriisikeskus@evira.fi ) }\end{array}$} \\
\hline Purpose & \multicolumn{5}{|c|}{$\begin{array}{l}\text { To initiate relevant responses in Norway. Test the email communication between } \\
\text { Norway and Finland. }\end{array}$} \\
\hline Expected reaction: & \multicolumn{5}{|c|}{$\begin{array}{l}\text { Inject message is sent from Finnish CVO to Norwegian CVO by e-mail. } \\
\text { The message recipient (CVO Norway) is expected to acknowledge receipt of the } \\
\text { request by sending a reply to CVO Finland, including a copy to the exercise } \\
\text { mailboxNBWNF@fvst.dk. }\end{array}$} \\
\hline \multicolumn{6}{|l|}{ Observed reaction: } \\
\hline Comments to DISTAFF: & \multicolumn{5}{|c|}{$\begin{array}{l}\text { If the recipient do not receive this information the DISTAFF representative must } \\
\text { inform the Finnish DISTAFF by sending an email to miia.kauremaa@evira.fi. } \\
\text { If the Norwegian CVO does not reply to the request before 14:45 (FIN 15:45), the } \\
\text { DISTAFF in Norway intervenes and initiates dispatch of a reply including a copy to } \\
\text { the exercise mailbox NBWNF@fVst.dk }\end{array}$} \\
\hline
\end{tabular}




\section{Annex 7 - Evaluation questionnaires}

NORDIC-BALTIC VETERINARY CONTINGENCY GROUP

\section{QUESTIONNAIRE}

Prepared for

The Evaluation of the Nordic-Baltic African swine fever simulation exercise, October 2011

\section{Background}

An African swine fever (ASF) simulation exercise will be conducted from $11-12$ October 2011 and involve all Nordic-Baltic countries.

The main objective of the ASF simulation exercise is to test National ASF Contingency Plans.

This questionnaire has been developed as a tool to assist the countries involved in the simulation exercise in evaluating the parts of the exercise which are related to:

- Communication

- Future training of personnel

\section{Completion of questionnaire}

This questionnaire has been completed by:

Name:

Institute/Veterinary administration: 


\section{Part I - Communication}

1. How did your veterinary administration receive information on the first African swine fever outbreak in the Nordic-Baltic region? (Please tick all that apply and indicate if no message received)

\begin{tabular}{|c|c|c|c|c|c|c|c|}
\hline $\begin{array}{l}\text { Information } \\
\text { from }\end{array}$ & Telephone & $\begin{array}{l}\text { Text } \\
\text { Message }\end{array}$ & Email & Fax & Letter & $\begin{array}{l}\text { Other } \\
\text { (specify) }\end{array}$ & $\begin{array}{l}\text { No information } \\
\text { received }\end{array}$ \\
\hline Denmark & & & & & & & \\
\hline Estonia & & & & & & & \\
\hline Finland & & & & & & & \\
\hline Latvia & & & & & & & \\
\hline Lithuania & & & & & & & \\
\hline Norway & & & & & & & \\
\hline Sweden & & & & & & & \\
\hline
\end{tabular}

2. How did you send information on the first African swine fever outbreak in your country to the other Nordic and Baltic countries? (Please tick all that apply)

\begin{tabular}{|c|c|c|c|c|c|c|c|}
\hline $\begin{array}{l}\text { Information } \\
\text { sent to }\end{array}$ & Telephone & $\begin{array}{l}\text { Text } \\
\text { Message }\end{array}$ & Email & Fax & Letter & $\begin{array}{l}\text { Other } \\
\text { (specify) }\end{array}$ & No information sent \\
\hline Denmark & & & & & & & \\
\hline Estonia & & & & & & & \\
\hline Finland & & & & & & & \\
\hline Iceland & & & & & & & \\
\hline Latvia & & & & & & & \\
\hline Lithuania & & & & & & & \\
\hline Norway & & & & & & & \\
\hline Sweden & & & & & & & \\
\hline
\end{tabular}

3. Who in your country was during the exercise responsible for sending information to other competent authorities in the Nordic-Baltic countries? 
4. Did you have a communication strategy as part of your African swine fever contingency plan or in another document?

$\square$ yes $\quad \square$ no

5. Did you set up or plan to have a specific area on your a web site for the new African swine fever situation in your country (suspicions and/or outbreaks)?

$\square$ yes $\quad \square$ no

6. Did you have information on African swine fever available for distribution to the media and farmers before the start of the simulation exercise?

$\square$ yes $\quad \square$ no

7. If yes what type of information? (Please tick all that applies).

\begin{tabular}{|l|l|l|l|l|l|}
\hline Type & Leaflets & books & Web pages & $\begin{array}{l}\text { Briefing for the } \\
\text { press }\end{array}$ & Advisory documents \\
\hline & & & & & \\
\hline
\end{tabular}

8. What went well with communications between Nordic- Baltic countries?

9. What could be improved?

10. Do you have any further comments that you wish to make about communications aspects of the exercise? 


\section{Part II - Future training of personnel}

The questions in part II has been prepared with the aim to evaluate the African swine fever simulation exercise and identify future training needs.

1. The Duration of the African swine fever simulation exercise was found to be (tick one box)

$\square$ too short $\square$ about right $\square$ could be longer $\square$ too long

Please give further explanation if required:

2. The Tasks in the exercise were found to be (tick 1 box)

$\square$ unrealistic $\square$ unusual $\square$ difficult but challenging $\square$ highly realistic

Please give further information if required:

3. Did you feel that you were adequately trained for the crisis management role?

$\square$ no $\square$ not really $\square$ yes but reservations $\square$ yes very

Please give further information if required:

4. Were the task and role in the exercise relevant for your daily work?

5. Were the objectives of the simulation exercise met?

$\square$ yes $\quad \square$ no

6. If no why not

7. What went well in the simulation exercise?

8. What could be improved?

9. Do you have any further comments that you wish to make about the African swine fever simulation exercise and any recommendations for future exercises and/or training requirements? 